\title{
An Improved Method for Concentrating Rotavirus from Water Samples
}

\section{Leera Kittigul/ ${ }^{+}$, Porntip Khamoun, Dusit Sujirarat*, Fuangfa Utrarachkij, Kitja Chitpirom, Nattasai Chaichantanakit, Kanda Vathanophas}

\author{
Department of Microbiology *Department of Epidemiology, Faculty of Public Health, Mahidol University, \\ 420/1 Rajvithi Road, Bangkok, 10400, Thailand
}

A modified adsorption-elution method for the concentration of seeded rotavirus from water samples was used to determine various factors which affected the virus recovery. An enzyme-linked immunosorbent assay was used to detect the rotavirus antigen after concentration. Of the various eluents compared, $0.05 \mathrm{M}$ glycine, $\mathrm{pH} 11.5$ gave the highest rotavirus antigen recovery using negatively charged membrane filtration whereas $2.9 \%$ tryptose phosphate broth containing 6\% glycine; $\mathrm{pH} 9.0$ was found to give the greatest elution efficiency when a positively charged membrane was used. Reconcentration of water samples by a speedVac concentrator showed significantly higher rotavirus recovery than polyethylene glycol precipitation through both negatively and positively charged filters (p-value <0.001). In addition, speedVac concentration using negatively charged filtration resulted in greater rotavirus recovery than that using positively charged filtration ( $p$-value $=0.004)$. Thirty eight environmental water samples were collected from river, domestic sewage, canals receiving raw sewage drains, and tap water collected in containers for domestic use, all from congested areas of Bangkok. In addition, several samples of commercial drinking water were analyzed. All samples were concentrated and examined for rotavirus antigen. Coliforms and fecal coliforms $\left(0_{-}>1,800 \mathrm{MPN} / 100 \mathrm{ml}\right)$ were observed but rotavirus was not detected in any sample. This study suggests that the speedVac reconcentration method gives the most efficient rotavirus recovery from water samples.

Key words: rotavirus - speedVac reconcentration - water samples

Rotaviruses cause acute gastroenteritis mainly in infants and young children admitted to hospital (Kapikian \& Chanock 1996). The viruses are excreted in large numbers in the feces of infected individuals. Waterborne outbreaks of rotavirus have been reported (Hopkins et al. 1984, Kukkula et al. 1997). Rotavirus was detected in sewage (Mehnert \& Stewien 1993, Gajardo et al. 1995, Dubois et al. 1997), river water (Gilgen et al. 1997), groundwater (Abbaszadegan et al. 1999), and drinking water (Jothikumar et al. 1995, GratacapCavallier et al. 2000). The presence of rotavirus in water and sewage indicates contamination of the virus in the environment. However, the density of virus in water is so low that virus concentration is

The study was supported by a grant from the China Medical Board, Faculty of Public Health, Mahidol University.

${ }^{+}$Corresponding author. Fax: +662-2458351. E-mail: phlkt@ mahidol.ac.th

Received 14 November 2000

Accepted 9 May 2001 necessary for detection. Several methods for concentrating waterborne viruses have been suggested but adsorption-elution from microporous filters seems to be the most promising technique (Guttman-Bass \& Armon 1983, Lewis \& Metcalf 1988, Li et al. 1998, Abbaszadegan et al. 1999). Although the reverse transcriptase-polymerase chain reaction (RT-PCR) technique was developed for direct detection of rotavirus double-stranded RNA (ds RNA) from water samples (Dubois et al. 1997), the virus concentration technique by adsorption-elution continues to be used for detection of rotavirus ds RNA (Gilgen et al. 1997, Abbas zadegan et al. 1999). Reconcentration methods carried out by aluminum hydroxide precipitation, polyethylene glycol precipitation, or organic flocculation, require the addition of polycationic salts and acidification of the primary eluate, thus leading to the possibility of virus loss (Lewis \& Metcalf 1988 , Toranzos \& Gerba 1989). The use of evaporation together with centrifugation by a speedVac concentrator as secondary concentration presented here could decrease the volume of the eluate efficiently and overcome the drawbacks of other reconcentration techniques.

The purpose of this study was to determine the factors that influence the concentration of rotavirus 
from water samples by using a modified adsorption-elution technique. The recoveries of rotavirus antigen in concentrated samples were examined by an enzyme-linked immunosorbent assay (ELISA).

\section{MATERIALS AND METHODS}

Virus concentration method - The technique for concentration of virus was carried out using a standard method (American Public Health Association 1992), with some modification. Inactivated bovine rotavirus was seeded in a tap water sample of 100 $\mathrm{ml}$. Prior to inactivation, the material contained approximately $10^{5}$ infectious forming units (IFU) per $\mathrm{ml}$, as determined by cell culture. Therefore, the amount of inactivated rotavirus in $100 \mathrm{ml}$ was $\sim 3.5 \times 10^{4}$ IFU. The tap water was dechlorinated by sodium thiosulfate with a final concentration of $50 \mathrm{mg} / \mathrm{l}$. For the negatively charged filter, the seeded tap water was preconditioned to acid $\mathrm{pH}$ at 3.5 with $1 \mathrm{~N} \mathrm{HCl}$ and its ionic condition was adjusted with $\mathrm{AlCl}_{3}$ to a final concentration of 0.0015 $\mathrm{N}$. The mixture was stirred for at least $30 \mathrm{~min}$. The tap water was placed in the adsorbent filter holder and passed through a GN-6 Metricel ${ }^{\circledR}$ filter, $47 \mathrm{~mm}$ in diameter and $0.45 \mu \mathrm{m}$ porosity (Gelman, Ann Arbor, MI). The membrane filter was washed with $0.15 \mathrm{~N} \mathrm{NaCl}, \mathrm{pH} 3.5$, to remove excess $\mathrm{Al}^{3+}$. The adsorbed virus was eluted by passing an eluent solution $(7.5 \mathrm{ml})$ through the filter. The primary eluate was neutralized to $\mathrm{pH} 7$ and the volume of the eluate was further reduced by reconcentration methods.

For the positively charged filter, seeded tap water at $\mathrm{pH} 8.0$ was passed through a Zetapor ${ }^{\circledR} 1$ MDS adsorbent filter, $47 \mathrm{~mm}$ in diameter and 0.2 $\mu \mathrm{m}$ porosity (AMT Cuno, Meriden, CT) without preconditioning the sample. The adsorbed virus was eluted with an eluent solution and the primary eluate was reconcentrated.

Eluents - Three groups of eluents containing tryptose phosphate broth (TPB), beef extract (BE), or glycine, were included in the virus concentration technique. The TPB eluates were $1 \%$ TPB + $6 \%$ glycine $+6 \%$ arginine $\mathrm{pH} 9.0$, and $2.9 \%$ TPB $+6 \%$ glycine $\mathrm{pH}$ 9.0. The BE eluates were $3 \% \mathrm{BE}$ $\mathrm{pH} 9.0$ and $3 \% \mathrm{BE}+0.05 \mathrm{M}$ glycine $\mathrm{pH} 9.5$. In the glycine group, $0.05 \mathrm{M}$ glycine $\mathrm{pH} 10.5$, and $0.05 \mathrm{M}$ glycine $\mathrm{pH} 11.5$, were used in the experiments.

\section{Reconcentration methods}

Organic flocculation - The method of reconcentration by organic flocculation was performed as described by Guttman-Bass and Armon (1983). Briefly, the primary eluate was seeded with rotavirus (3.5X104 IFU) and the $\mathrm{pH}$ was lowered to 3.5 , while shaking at room temperature for 30 $\min$. The eluate was centrifuged at $3,000 \mathrm{xg}$ for
$10 \mathrm{~min}$. Then, the pellet was dissolved in a $1 / 20$ vol. of $0.15 \mathrm{M} \mathrm{NaH} \mathrm{NO}_{4} / \mathrm{Na}_{2} \mathrm{HPO}_{4}, \mathrm{pH} 7.5$ and stored at $-80^{\circ} \mathrm{C}$ until viral assay.

Polyethylene glycol precipitation - Reconcentration by polyethylene glycol (PEG) precipitation was carried out essentially as described by Lewis and Metcalf (1988), with some modification. The primary eluate was brought to $3 \%$ beef extract and adjusted to $\mathrm{pH} 7.5$. PEG (MW 6,000) was added to a final concentration of $8 \%$. The eluate was stirred at $4^{\circ} \mathrm{C}$ for $2 \mathrm{~h}$ and centrifuged at $10,000 \mathrm{x} \mathrm{g}$ for $20 \mathrm{~min}$. The pellet was suspended in $0.15 \mathrm{M} \mathrm{NaH}{ }_{2} \mathrm{PO}_{4} / \mathrm{Na}_{2} \mathrm{HPO}_{4}$, pH 9.0 and sonicated at high frequency $(20 \mathrm{kHz} \pm 50 \mathrm{~Hz})$ with a sonicator (Sonics \& Materials, Danbury, CT) for $30 \mathrm{sec}$. Next, the suspension was shaken at room temperature for $20 \mathrm{~min}$, and centrifuged again at $10,000 \mathrm{x} g$ for $30 \mathrm{~min}$. Finally, the supernatant was collected and stored at $-80^{\circ} \mathrm{C}$ until use.

SpeedVac concentration - A speedVac instrument (Savant, Famingdale, NY) was used for reconcentrating the primary eluate. The technique combined centrifugal force, vacuum, and heating at medium temperature $\left(43^{\circ} \mathrm{C}\right)$ for solvent removal and sample concentration. It took $4 \mathrm{~h}$ for concentration of the eluate $(7.5 \mathrm{ml})$ to a final volume of $0.5-1 \mathrm{ml}$. The concentrated eluate was stored at $80^{\circ} \mathrm{C}$ until assay.

Rotavirus ELISA - The presence of rotavirus antigen in the concentrated eluate was determined by a commercial rotavirus test kit (IDEIA ${ }^{\mathrm{TM}}$ Dako, Cambridshire, UK) following the procedure recommended by the manufacturer.

Water samples - Water samples were collected in sterile 1-liter bottles from a river (4 samples), domestic sewage (8 samples) and canals receiving raw sewage drains (12 samples), all located in congested areas of Bangkok. Tap water collected in containers for domestic use (10 samples) and commercial drinking water (4 samples from different producers) were also obtained in sterile 5-liter bottles. Temperature and $\mathrm{pH}$ of all 38 samples were measured. The samples were transported to the laboratory in an ice box. Coliforms and fecal coliforms were identified by bacteriological methods (Hitchins et al. 1992). The water samples were concentrated in optimal conditions and determined for rotavirus antigen by using the IDEIA ${ }^{\mathrm{TM}} \mathrm{kit}$.

The experiments comparing virus concentration methods are described in Figs 1, 2, 3. The environmental water samples were processed according to the scheme shown in Fig. 4.

Data analysis - Recovery rates of rotavirus antigen were calculated as the percentage of OD value of the spiked virus after concentration compared with that before the concentration process. Analysis of variance was used to determine the 
Spike inactivated bovine rotavirus in tap water, $100 \mathrm{ml}$

Add sodium thiosulfate to $50 \mathrm{mg} / \mathrm{l}$

Part I: adjust $\mathrm{pH}$ to 3.5 , add $\mathrm{AlCl}_{3}$ to $0.0015 \mathrm{~N}$ and stir for $30 \mathrm{~min}$

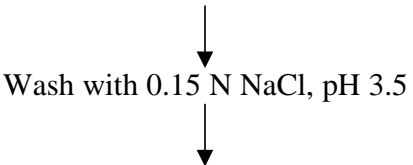

Part II: elute with each eluent of the following groups:

TPB group $-1 \%$ TPB $+6 \%$ glycine $+6 \%$ arginine, $\mathrm{pH} 9.0$

or $2.9 \% \mathrm{TPB}+6 \%$ glycine, $\mathrm{pH} 9.0$

$\mathrm{BE}$ group $-3 \% \mathrm{BE}, \mathrm{pH} 9.0$ or $3 \% \mathrm{BE}+0.05 \mathrm{M}$ glycine, $\mathrm{pH} 9.5$

Glycine group - $0.05 \mathrm{M}$ glycine, $\mathrm{pH} 10.5$ or $0.05 \mathrm{M}$ glycine, $\mathrm{pH} 11.5$

Adjust to $\mathrm{pH} 7$ and reconcentrate by speedVac

ELISA using a commercial rotavirus test kit

Fig. 1: rotavirus concentration method using negatively charged membrane filtration: various eluents

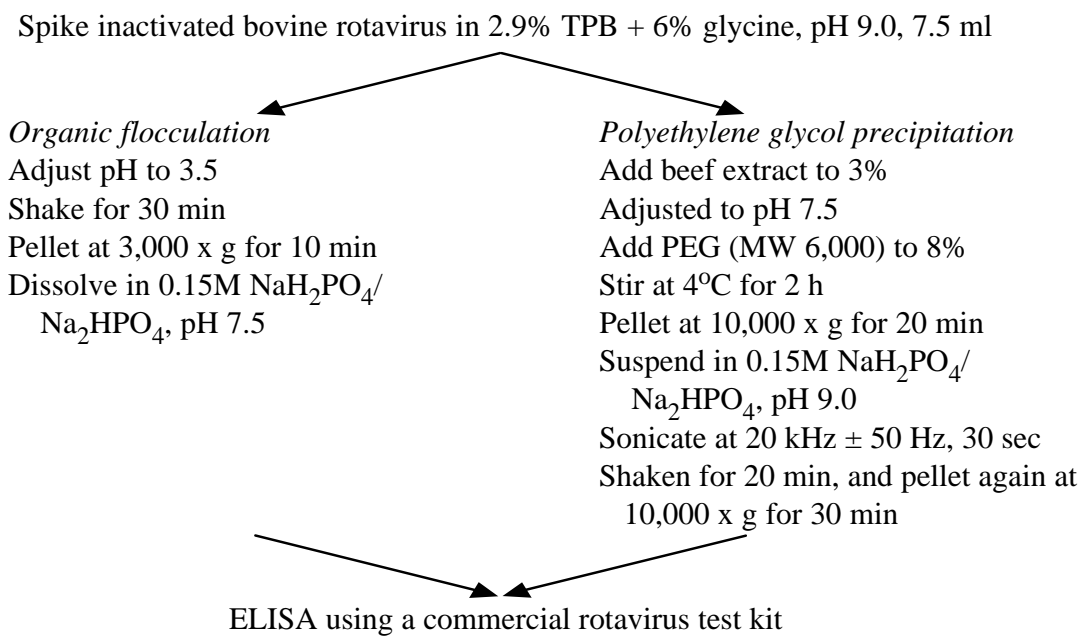

Fig. 2: rotavirus reconcentration methods

effects of various factors. Such effects were confirmed by analysis of one way ANOVA for three variables or $\mathrm{t}$-test for two variables in each factor.

\section{RESULTS}

Effect of eluents, and reconcentration methods Various eluents were compared using a negatively charged membrane filter (Fig. 1). After triplicate experiments, $0.05 \mathrm{M}$ glycine, $\mathrm{pH} 11.5$, gave the highest mean recovery $(53 \%)$ followed by $2.9 \% \mathrm{TPB}+$ $6 \%$ glycine, $\mathrm{pH} 9.0(47.9 \%)$ and $3 \% \mathrm{BE}+0.05 \mathrm{M}$ glycine, $\mathrm{pH} 9.5(37.7 \%)$. The use of $6 \%$ arginine in $1 \%$ TPB and $6 \%$ glycine gave a rotavirus recovery of $43.1 \%$. After passing the same eluent five times, the rotavirus recovery was lower than passing just once in both $2.9 \% \mathrm{TPB}+6 \%$ glycine, $\mathrm{pH} 9.0$ and 


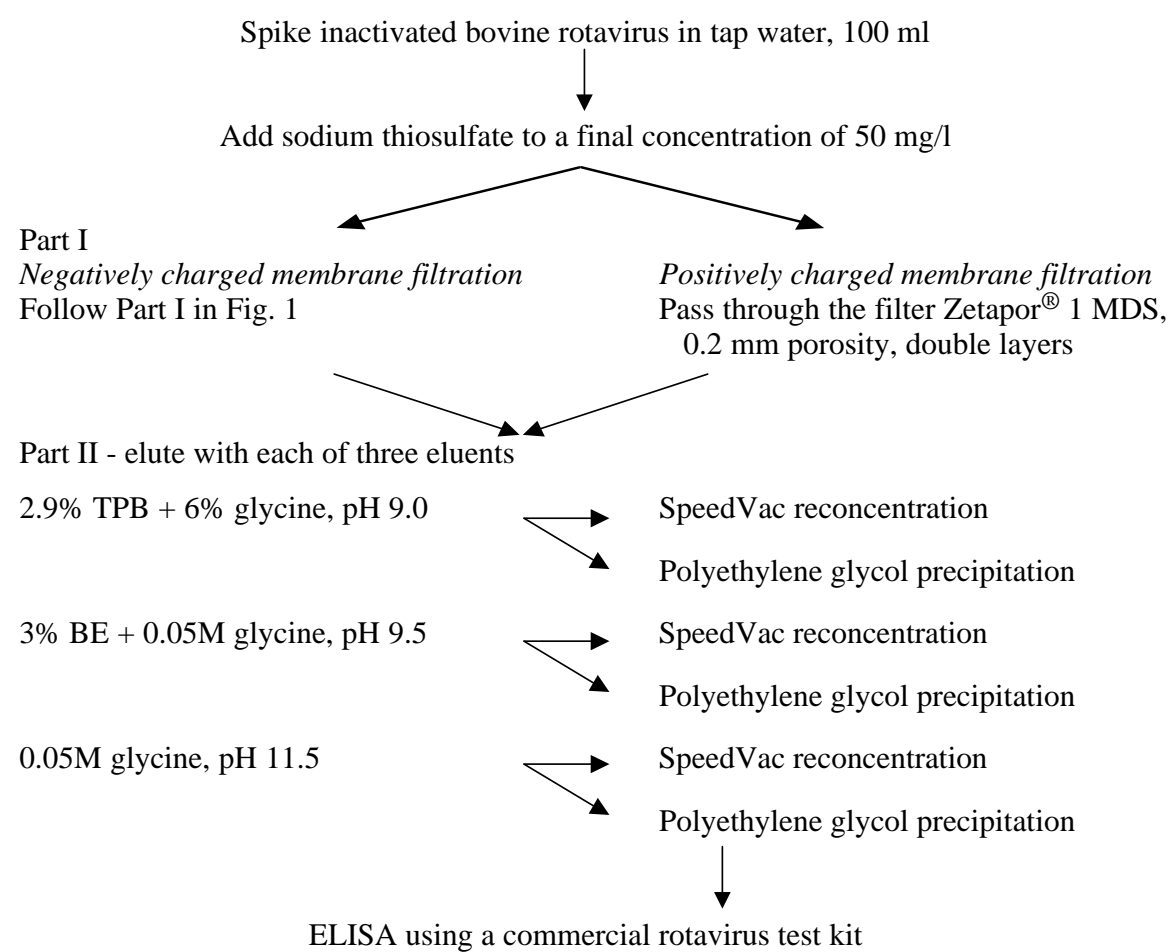

Fig. 3: rotavirus concentration using different membrane filters, eluents and reconcentration methods.

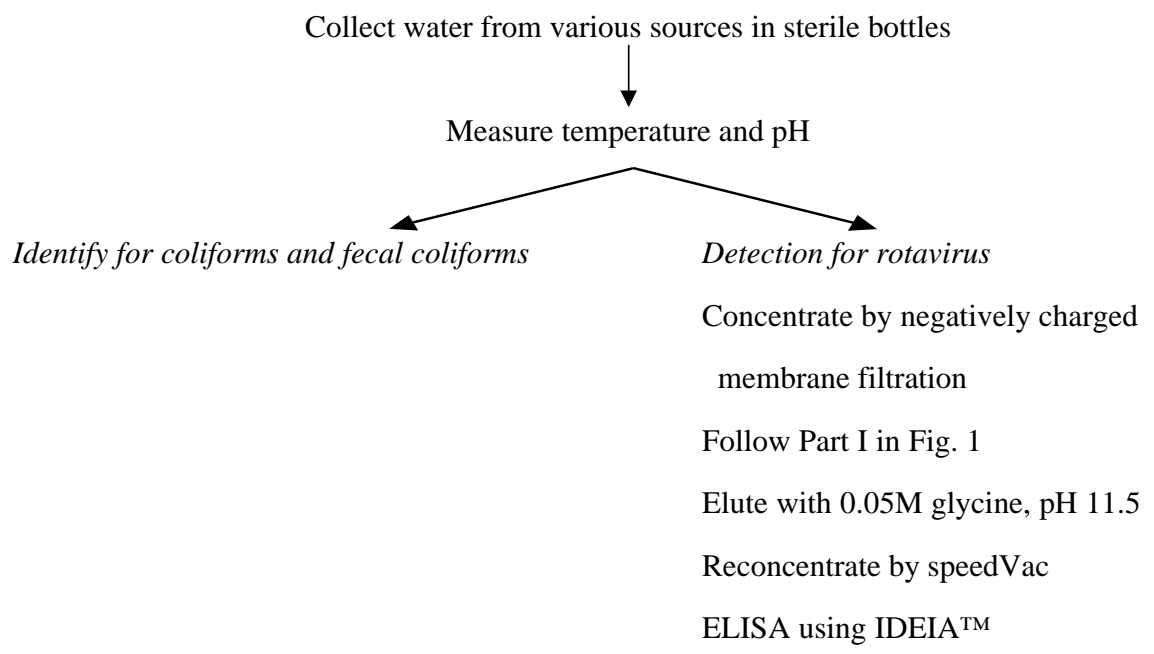

Fig. 4: processing of environmental water samples (11 or 5l)

$0.05 \mathrm{M}$ glycine, $\mathrm{pH} 10.5$, as shown in Table I. The three different kinds of eluents which gave the highest recoveries of rotavirus were further assayed. These eluents included $0.05 \mathrm{M}$ glycine $\mathrm{pH} 11.5,2.9 \%$ $\mathrm{TPB}+6 \%$ glycine $\mathrm{pH} 9.0$, and $3 \% \mathrm{BE}+0.05 \mathrm{M}$ glycine $\mathrm{pH} 9.5$. In the comparison of the two reconcentration methods (Fig. 2), less rotavirus was recovered using organic flocculation $(23.3 \%)$ than with PEG precipitaion (45.7\%). The three eluents and the two reconcentration methods (PEG precipitation and speedVac concentration) were compared during the use of positively and negatively charged membrane filtration (Fig. 3).

Rotavirus recovery on different conditions When negatively charged filtration and speedVac reconcentration were used, $0.05 \mathrm{M}$ glycine, $\mathrm{pH} 11.5$ 
gave the highest rotavirus recovery of $56.6 \pm 2.7 \%$ (mean $\pm \mathrm{SD}$ ) followed by $2.9 \% \mathrm{TPB}+6 \%$ glycine, $\mathrm{pH} 9.0(41.2 \pm 13.6 \%)$ and $3 \% \mathrm{BE}+0.05 \mathrm{M}$ glycine, $\mathrm{pH} 9.5(37.6 \pm 5.3 \%)$. Whatever eluents were used, reconcentration by PEG precipitation recovered less than half of the virus, as shown in Table II.

Lower recoveries were observed using positively charged filtration. With speedVac reconcentration, $2.9 \%$ TPB $+6 \%$ glycine, $\mathrm{pH} 9.0$ gave the highest rotavirus recovery of $34.9 \pm 8.4 \%$ followed by $3 \% \mathrm{BE}+0.05 \mathrm{M}$ glycine, $\mathrm{pH} 9.5(28.2$ $\pm 5.7 \%)$ and $0.05 \mathrm{M}$ glycine, $\mathrm{pH} 11.5(25.3 \pm 0.1 \%)$ whereas PEG precipitation gave a much lower rotavirus recovery (Table III).

Factors influencing virus concentration method - The three different kinds of eluent did not affect the efficiency of rotavirus concentration. The use of speedVac concentration increased the efficiency of the virus concentration method significantly over PEG precipitation when using both negatively and positively charged membranes, $p$-value $<0.001$. Moreover, reconcentration by a speedVac concentrator gave a significantly higher virus recovery in negatively charged filtration than that in positively charged filtration with a $p$-value of 0.004 , as shown in Table IV.

Rotavirus antigen in environmental water samples - The modified adsorption-elution method was used to determine rotavirus antigen in water samples collected from various sources with a use of a negatively charged filter, $0.05 \mathrm{M}$ glycine, $\mathrm{pH}$ 11.5, and speedVac concentration (Fig. 4). The environmental water samples had $\mathrm{pH}$ and temperature in the range of 7.23-8.75 and 28-32, respectively. After reconcentration, the water samples were concentrated 2,000-10,000 fold. Although coliforms and fecal coliforms (0->1,800 MPN/ml) were found in water samples collected from sewage, canals, river and tap water in containers for drinking or domestic uses, rotavirus antigen was not detected by a commercial ELISA kit.

\section{TABLE I}

Recovery of rotavirus antigen using negatively charged filters with different eluents

\begin{tabular}{|c|c|c|c|c|}
\hline \multirow[t]{2}{*}{ Eluent } & \multicolumn{4}{|c|}{ Rotavirus antigen recovered $(\%)^{a}$} \\
\hline & No. 1 & No. 2 & No. 3 & Mean $(\bar{x})$ \\
\hline $1 \% \mathrm{TPB}+6 \%$ glycine $+6 \%$ arginine, $\mathrm{pH} 9.0$ & 43.13 & ND & ND & 43.13 \\
\hline $2.9 \%$ TPB $+6 \%$ glycine, $\mathrm{pH} 9.0$ & 52.42 & 50.58 & 40.85 & 47.95 \\
\hline $2.9 \% \mathrm{TPB}+6 \%$ glycine, $\mathrm{pH} 9.0,5$ times $^{b}$ & 30.22 & ND & ND & 30.22 \\
\hline $3 \%$ BE, pH 9.0 & 41.64 & 35.73 & 34.70 & 37.36 \\
\hline $3 \% \mathrm{BE}+0.05 \mathrm{M}$ glycine, $\mathrm{pH} 9.5$ & 42.68 & 33.46 & 37.09 & 37.74 \\
\hline $0.05 \mathrm{M}$ glycine, $\mathrm{pH} 10.5$ & 59.56 & ND & ND & 59.56 \\
\hline $0.05 \mathrm{M}$ glycine, $\mathrm{pH} 10.5,5$ times $^{b}$ & 43.69 & ND & ND & 43.69 \\
\hline $0.05 \mathrm{M}$ glycine, $\mathrm{pH} 11.5$ & 62.03 & 50.99 & 46.03 & 53.02 \\
\hline
\end{tabular}

$a$ : tap water, $100 \mathrm{ml}$ was spiked with $350 \mu \mathrm{l}$ of rotavirus $\left(10^{5}\right.$ infectious forming units $\left./ \mathrm{ml}\right) ; b$ : the filter was eluted with the same eluent for 5 times; ND: not determined.

\section{TABLE II}

Recovery of rotavirus concentrated by negatively charged filtration with three different eluents on speedVac concentration or polyethylene glycol (PEG) 6000 precipitation

\begin{tabular}{|c|c|c|c|c|c|c|}
\hline \multirow{3}{*}{$\begin{array}{l}\text { Eluents } \\
\text { Experiment }^{a}\end{array}$} & \multicolumn{6}{|c|}{ Rotavirus recovered $(\%)$} \\
\hline & \multicolumn{2}{|c|}{$2.9 \%$ TPB $+6 \%$ glycine $\mathrm{pH} 9.0$} & \multicolumn{2}{|c|}{$3 \% \mathrm{BE}+0.05 \mathrm{M}$ glycine $\mathrm{pH} 9.5$} & \multicolumn{2}{|c|}{$0.05 \mathrm{M}$ glycine $\mathrm{pH} 11.5$} \\
\hline & $\begin{array}{r}\text { SpeedVac } \\
\text { concentration }\end{array}$ & $\begin{array}{c}\text { PEG } \\
\text { precipitation }\end{array}$ & $\begin{array}{c}\text { SpeedVac } \\
\text { concentration }\end{array}$ & $\begin{array}{c}\text { PEG } \\
\text { precipitation }\end{array}$ & $\begin{array}{c}\text { SpeedVac } \\
\text { concentration }\end{array}$ & $\begin{array}{c}\text { PEG } \\
\text { precipitation } \\
\end{array}$ \\
\hline No. 1 & & & 34. & & 57 & 17.80 \\
\hline No. 2 & 36.86 & 14.82 & 34.48 & 16.14 & 58.46 & 22.76 \\
\hline No .3 & 56.32 & 23.29 & 43.66 & 19.85 & 53.55 & 23.08 \\
\hline $\operatorname{Mean}(\overrightarrow{\mathrm{x}}) \pm \mathrm{SI}$ & $41.22 \pm 13.58$ & $18.76 \pm 4.27$ & $37.57 \pm 5.27$ & $15.37 \pm 4.91$ & $56.59 \pm 2.66$ & $21.21 \pm 2.96$ \\
\hline
\end{tabular}

$a$ : tap water, $100 \mathrm{ml}$ was spiked with $350 \mu \mathrm{l}$ of rotavirus ( $10^{5}$ infectious forming units $\left./ \mathrm{ml}\right)$, concentrated by adsorptionelution technique using a negatively charged membrane (GN-6, Metricel with $0.45 \mu \mathrm{m}$ porosity) and reconcentrated by speedVac concentration or polyethylene glycol (PEG) 6000 precipitation. 


\section{TABLE III}

Recovery of rotavirus concentrated by positively charged filtration with three different eluents and speedVac concentration or polyethylene glycol (PEG) 6000 precipitation

\begin{tabular}{|c|c|c|c|c|c|c|}
\hline \multirow{3}{*}{$\begin{array}{l}\text { Eluents } \\
\text { Experiment }{ }^{a}\end{array}$} & \multicolumn{6}{|c|}{ Rotavirus recovered $(\%)$} \\
\hline & \multicolumn{2}{|c|}{$2.9 \%$ TPB $+6 \%$ glycine $\mathrm{pH} 9.0$} & \multicolumn{2}{|c|}{$3 \% \mathrm{BE}+0.05 \mathrm{M}$ glycine $\mathrm{pH} 9.5$} & \multicolumn{2}{|c|}{$0.05 \mathrm{M}$ glycine $\mathrm{pH} 11.5$} \\
\hline & $\begin{array}{r}\text { SpeedVac } \\
\text { concentration }\end{array}$ & $\begin{array}{c}\text { PEG } \\
\text { precipitation }\end{array}$ & $\begin{array}{c}\text { SpeedVac } \\
\text { concentration }\end{array}$ & $\begin{array}{c}\text { PEG } \\
\text { precipitation }\end{array}$ & $\begin{array}{c}\text { SpeedVac } \\
\text { concentration }\end{array}$ & $\begin{array}{c}\text { PEG } \\
\text { precipitation }\end{array}$ \\
\hline No. 1 & 44.57 & 17.03 & 34.74 & 23.51 & 25.14 & 16.30 \\
\hline No. 2 & 30.13 & 13.73 & 24.59 & 20.73 & 25.32 & 13.46 \\
\hline No. 3 & 29.87 & 12.93 & 25.32 & 20.20 & 25.32 & 13.73 \\
\hline $\operatorname{Mean}(\overline{\mathrm{x}}) \pm \mathrm{SD}$ & $34.86 \pm 8.41$ & $14.56 \pm 2.17$ & $28.22 \pm 5.66$ & $21.48 \pm 1.78$ & $25.26 \pm 0.10$ & $14.50 \pm 1.57$ \\
\hline
\end{tabular}

$a$ : tap water, $100 \mathrm{ml}$ was spiked with $350 \mu \mathrm{l}$ of rotavirus $\left(10^{5}\right.$ infectious forming units $\left./ \mathrm{ml}\right)$, passed through positively charged membranes (double layers of Zetapor, $0.20 \mu \mathrm{m}$ ). After elution, the sample was reconcentrated by speedVac concentration or polyethylene glycol (PEG) 6000 precipitation.

\section{TABLE IV}

Recovery of rotavirus concentrated by negatively or positively charged membrane filtration with different eluents and reconcentration methods

\begin{tabular}{|c|c|c|c|}
\hline Characteristics & $\begin{array}{c}\text { Negative charged filter } \\
\text { Mean } \pm \text { SD }\end{array}$ & $\begin{array}{c}\text { Positive charged filter } \\
\text { Mean } \pm \text { SD }\end{array}$ & $p$-value \\
\hline \multicolumn{4}{|l|}{ Eluents } \\
\hline $2.9 \%$ ТPB + 6\% glycine, $\mathrm{pH} 9.0$ & $29.99 \pm 15.22$ & $24.71 \pm 12.40$ & NA \\
\hline $3 \% \mathrm{BE}+0.05 \mathrm{M}$ glycine, $\mathrm{pH} 9.5$ & $26.47 \pm 12.98$ & $24.85 \pm 5.26$ & NA \\
\hline $0.05 \mathrm{M}$ glycine, $\mathrm{pH} 11.5$ & $38.90 \pm 19.54$ & $19.88 \pm 5.98$ & NA \\
\hline$p$-value & $0.411^{a}$ & $0.529^{a}$ & \\
\hline \multicolumn{4}{|l|}{ Reconcentration methods } \\
\hline SpeedVac concentration & $45.13 \pm 11.44$ & $29.44 \pm 6.62$ & $0.004^{b}$ \\
\hline PEG precipitation & $18.45 \pm 4.38$ & $16.85 \pm 3.83$ & $0.421^{b}$ \\
\hline$p$-value & $<0.001^{b}$ & $<0.001^{b}$ & \\
\hline
\end{tabular}

NA: not analyzed; $a$ : one way ANOVA; $b$ : t-test

\section{DISCUSSION}

Of the eluents used, $0.05 \mathrm{M}$ glycine, $\mathrm{pH} 11.5$ gave the highest mean recovery after triplicate experiments. The primary eluate was simply adjusted to $\mathrm{pH} 7.0$ to avoid the possibility of appreciable virus inactivation because it contained phenol red, as a $\mathrm{pH}$ indicator. To reduce the possibility of viral inactivation at $\mathrm{pH} 11.5$, elution with glycine, $\mathrm{pH}$ 10.5 , was attempted but it was observed that elution with this solution gave lower and more erratic recoveries than did elution at $\mathrm{pH} 11.0$ (Farrah et al. 1976). Three percent BE gave a rotavirus recovery lower than elution with glycine buffer although BE was observed to be a more efficient eluent than glycine buffer in other studies (Sobsey \& Glass 1980, Guttman-Bass \& Armon 1983). In positively charged filtration, the efficiency of virus concentration method was greatly reduced by elution with $0.05 \mathrm{M}$ glycine, $\mathrm{pH} 11.5$ but was not when $2.9 \%$ TPB $+6 \%$ glycine, $\mathrm{pH} 9.0$ was used. This indicates that the latter might be an appropri- ate eluent for both negatively and positively charged membranes.

SpeedVac reconcentration yielded the highest rotavirus recovery. The evaporation combined with centrifugation simultaneously reduced the volume of the eluate and concentrated the samples 2,00010,000 fold. The use of a speedVac concentrator in the second step of rotavirus concentration allowed for the reduction of eluate volume without the need for the addition of cationic salts and acidification. This method has several advantages over the existing PEG precipitation and organic flocculation procedures. Furthermore, we found that at least one virus (poliovirus) is not inactivated during the reconcentration process, as determined by cell culture isolation (unpublished observation).

The positively charged membrane could absorb virus without preconditioning of water at acid $\mathrm{pH}$ or addition of $\mathrm{AlCl}_{3}$ but it gave a lower recovery and significantly different results compared with the negatively charged membrane. Therefore the 
optimum condition for rotavirus concentration method was negatively charged filtration, elution with $0.05 \mathrm{M}$ glycine, $\mathrm{pH} 11.5,2.95 \mathrm{TPB}+6 \%$ glycine, $\mathrm{pH} 9.0$ or $3 \% \mathrm{BE}+0.05 \mathrm{M}$ glycine, $\mathrm{pH} 9.5$, and reconcentration by speedVac. Using this technique, rotavirus antigen has been detected in domestic sewage (Kittigul et al. 2000). In this study, rotavirus antigen was not detected in any sample. This may be due to the different sites of sample collection. Eluents containing BE should be avoided because it can cause non-specific reaction in ELISA (Jansons \& Bucens 1986) and inhibition of virus detection by the RT-PCR technique (Kopecka et al. 1993, Schwab et al. 1993). The application of a commercial ELISA was reported for determination of rotavirus antigen in environmental water samples with high sensitivity and specificity (Dahling et al. 1993). Although rotavirus was not detected by a commercial ELISA in the present study, it is emphasized that the use of modified adsorption-elution technique in optimum condition and speedVac reconcentration is an effective method for rotavirus concentration from water samples.

\section{REFERENCES}

Abbaszadegan M, Stewart P, LeChevallier M 1999. A strategy for detection of viruses in groundwater by PCR. Appl Environ Microbiol 65: 444-449.

American Public Health Association 1992. Standard Methods for the Examination of Water and Wastewater, 18th ed., American Public Health Association, Washington DC, p. 9-101-9-116.

Dahling DR, Wright BA, Williams FP 1993. Detection of viruses in environmental samples: suitability of commercial rotavirus and adenovirus test kit. J Virol Methods 45: 137-147.

Dubois E, Le Guyader F, Haugarreau L, Kopecka H, Cormier M, Pommepuy M 1997. Molecular epidemiological survey of rotaviruses in sewage by reverse transcriptase seminested PCR and restriction fragment length polymorphism assay. Appl Environ Microbiol 63: 1794-1800.

Farrah SR, Gerba CP, Willis C, Melnick JL 1976. Concentration of viruses from large volumes of tap water using pleated membrane filters. Appl Environ Microbiol 31: 221-226.

Gajardo R, Bouchriti N, Pinto RM, Bosch A 1995. Genotyping of rotaviruses isolated from sewage. Appl Environ Microbiol 61: 3460-3462.

Gilgen M, Germann D, Luthy J, Hubner Ph 1997. Threestep isolation method for sensitive detection of enterovirus, rotavirus, hepatitis A virus, and small round structured viruses in water samples. Int J Food Microbiol 37: 189-199.

Gratacap-Cavallier B, Genoulaz O, Brengel-Pesce K, Soule H, Innocenti-Francillard P, Bost M, Gofti L, Zmirou D, Seigneurin JM 2000. Detection of human and animal rotavirus sequences in drinking water. Appl Environ Microbiol 66: 2690-2692.
Guttman-Bass N, Armon R 1983. Concentration of simian rotavirus SA11 from tap water by membrane filtration and organic flocculation. Appl Environ Microbiol 45: 850-855.

Hitchins AD, Feng P, Watkins WD, Rippey SR, Chandler LA 1992. Escherichia coli and the coliform bacteria. In Bacteriological Analytical Manual, 7th ed., Food and Drug Administration, AOAC International, Arlington, p. 27-49.

Hopkins RS, Gaspard GB, Williams Jr FP, Karlin RJ, Cukor G, Blacklow NR 1984. A community waterborne gastroenteritis outbreak: evidence for rotavirus as the agent. Am J Public Health 74: 263-265.

Jansons J, Bucens MR 1986. Concentration of rotavirus by ultrafiltration. Water Res 20: 79-83.

Jothikumar N, Khanna P, Paulmurugan R, Kamatchiammal S, Padmanabhan P 1995. A simple device for the concentration and detection of enterovirus, hepatitis E virus and rotavirus from water samples by reverse transcription-polymerase chain reaction. J Virol Methods 55: 401-415.

Kapikian AZ, Chanock RM 1996. Rotaviruses. In BN Fields, DM Knipe, PM Howley, RM Chanock, JL Melnick, TP Monath, B Roizman, SE Straus (eds), Fields Virology, 3rd ed., Lippincott-Raven, Philadelphia, p. 1657-1708.

Kittigul L, Raengsakulrach B, Siritantikorn S, Kanyok R, Utrarachkij F, Diraphat P, Thirawuth V, Siripanichgon K, Pungchitton S, Chitpirom K, Chaichantanakit N, Vathanophas K 2000. Detection of poliovirus, hepatitis A virus and rotavirus from sewage and water samples. Southeast Asian J Trop Med Public Health 31: 41-46.

Kopecka H, Dubrou S, Prevot J, Marechal J, Lopez-Pila JM 1993. Detection of naturally occurring enteroviruses in waters by reverse transcription, polymerase chain reaction, and hybridization. Appl Environ Microbiol 59: 1213-1219.

Kukkula M, Arstila P, Klossner ML, Maunula L, Bonsdorff CH, Jaatinen P 1997. Waterborne outbreak of viral gastroenteritis. Scand J Infect Dis 29: 415-418.

Lewis GD, Metcalf TG 1988. Polyethylene glycol precipitation for recovery of pathogenic viruses, including hepatitis A virus and human rotavirus, from oyster, water, and sediment samples. Appl Environ Microbiol 54: 1983-1988.

Li JW, Wang XW, Rui QY, Song N, Zhang FG, Ou YC, Chao FH 1998. A new and simple method for concentration of enteric viruses from water. $J$ Virol Methods 74: 99-108.

Mehnert DU, Stewien KE 1993. Detection and distribution of rotavirus in raw sewage and creeks in São Paulo, Brazil. Appl Environ Microbiol 59: 140-143.

Schwab KJ, De Leon R, Sobsey MD 1993. Development of PCR methods for enteric virus detection in water. Wat Sci Tech 27: 211-218.

Sobsey MD, Glass JS 1980. Poliovirus concentration from tap water with electropositive adsorbent filters. Appl Environ Microbiol 40: 201-210.

Toranzos GA, Gerba CP 1989. An improved method for the concentration of rotaviruses from large volumes of water. J Virol Methods 24: 131-140. 